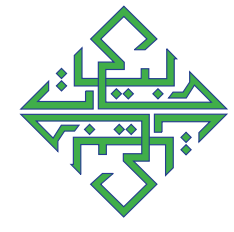

\title{
ANALISIS TERJEMAHAN TEKS AKADEMIK MAHASISWA PROGRAM STUDI PENDIDIKAN BAHASA ARAB
}

\author{
N. Lalah Alawiyah, Ahmad Royani, Mukhshon Nawawi \\ Universitas Islam Negeri Syarif Hidayatullah Jakarta \\ E-mail: lalah@uinjkt.ac.id
}

Naskah diterima: 18 September 2016, direvisi: 12 Oktober 2016, disetujui: 20 Nopember 2016.

\begin{abstract}
This research was aimed to deal with the research question about how the strategy was used to translate Indonesian language academic texts into Arabic in structural aspect, its strategy in semantical aspect, and its appropriateness in terminological aspect. Qualitative research was applied in this study and content analysis was used for the analysis. The source of this research was the authentic examples of the students' work Department of Arabic Education UIN Syarif Hidayatullah in translation subject. The data used in this study were the verbal expressions in students' works. The result found from 150 identified strategies, it was found 7 translation strategies discovered from students' works from Indonesian language into Arabic. Based on the strategies found, it can be concluded that the translation of academic texts was still oriented to the first language. From the aspect of target language, the academic terminology was appropriately used, standardized and clear, although some mistakes found from the aspect of structure.
\end{abstract}

Keywords: translation, translation strategy, Arabic language

\begin{abstract}
Abstrak
Penelitian ini bertujuan untuk menjawab permasalahan penelitian tentang strategi penerjemahan teks akademik bahasa Indonesia ke bahasa Arab dalam aspek struktural, strateginya dalam aspek semantis dan ketepatannya dalam aspek peristilahan.Penelitian ini menggunakan ancangan kualitatif dengan metode analisis isi. Sumber data dalam penelitian ini adalah contoh-contoh otentik hasil pekerjaan mahasiswa jurusan Pendidikan Bahasa Arab Semester VI FITK UIN Syarif Hidayatullah dalam mata kuliah Tarjamah.Data dalam penelitian ini berupa ungkapan verbal dalam hasil pekerjaan mahasiswa. Hasil penelitian menunjukkan dari 150 strategi yang teridentifikasi, ditemukan 6 bentuk strategi penerjemahan yang muncul dari teks otentik hasil terjemahan mahasiswa dari bahasa Indonesia ke bahasa Arab. Berdasarkan strategi-strategi yang ditemukan dapat ditegaskan bahwa penerjemahan teks akademik cenderung berorientasi kepada bahasa sumber (BSu). Dari aspek peristilahan yang digunakan dalam bahasa sasaran (BSa), penggunaan istilah akademik sudah benar, baku dan jelas, walaupun masih ditemukan kesalahan dari aspek struktur.
\end{abstract}

Kata Kunci: terjemah, strategi terjemah, bahasa Arab

How to Cite : Alawiyah, N. Lalah, et. all. "Terjemahan Teks Akademik Mahasiswa Program Studi PendidikanBahasa Arab" Arabiyat:JurnalPendidikanBahasaArabdanKebahasaaraban [Online], Volume 3 Number 2 (31 December 2016)

Permalink/DOI: http://dx.doi.org/10.15408/a.v3i2.4642 


\section{Pendahuluan}

Aktivitas menerjemahkan merupakan salah satu kegiatan yang banyak dilakukan mahasiswa programstudibahasaasing,tidak terkecuali dalam hal ini mahasiswa program studi Pendidikan Bahasa Arab. Kegiatan menerjemahkan ini tidak dilakukan hanya pada kegiatan mata kuliah Tarjamah saja, akan tetapi dilakukan juga pada mata kuliah lainnya yang relevan, seperti mata kuliah Qira'ah (Membaca). Intensitas kegiatan menerjemahkan ini semakin meningkat terutama ketika mahasiswa sedang menulis tugas akhir skripsi yang ditulis dalam bahasa Arab, misalnya menerjemahkan kutipan-kutipan dari buku-buku berbahasa Indonesia ke dalam bahasa Arab.

Oleh karena itu, mata kuliah Tarjamah menjadi penting bagi mahasiswa program studi Pendidikan Bahasa Arab. Menurut Syihabuddin, penerjemahan yang disajikan dalam bentuk mata kuliah ini bertujuan untuk membekali mahasiswa keterampilan dasar dalam menerjemah sehingga dapat membantu mahasiswa dalam mendalami mata kuliah lain yang memiliki keterkaitan. ${ }^{1}$ Dalam hal ini mahasiswa banyak dilibatkan dalam kegiatan penerjemahan teks-teks bergenre akademik

Meskipun mata kuliah Tarjamah diberikan pada program studi Pendidikan Bahasa Arab sudah sejak lama, namun penelitian tentang kompetensi menerjemah masih belum banyak dilakukan bahkan masih sangat minim. Sarrukai (2001) dalam Peterlin menyatakan bahwa penerjemahan yang melibatkan teks akademik masih belum mendapat perhatian atau bahkan terabaikan. $^{2}$

1 Syihabuddin, Penerjemahan Arab Indonesia (Teori dan Praktik), (Bandung: Humaniora, 2005), h.183

Agnes Pisanski Peterlin, "The Thesis Stat ment in Translation of Academic Discourse: an Exploratory Study" The Journal of Specialised Transla-
Oleh karena itu, penelitian ini menjadi signifikan untuk mengisi kerumpangan tersebut sehingga dapat memberikan data tentang kemampuan mahasiswa terkait kemampuan menerjemahkan dan sebagai evaluasi untuk mengukur kemampuan mereka yang pada akhirnya dapat dijadikan pijakan dalam upaya perbaikan pengajaran Tarjamah di program studi Pendidikan Bahasa Arab. Adapun yang dimaksud dengan evaluasi dalam penelitian ini adalah mengukur kompetensi mahasiswa dalam menerjemah yang tidak hanya pada tataran teoritis akan tetapi juga pada tataran praktis. Menurut Larson, yang menjadi fokus dalam penilaian terjemah adalah ketepatan dan kejelasan dalam menerjemah. ${ }^{3}$

Pada dasarnya, penelitian tentang produk penerjemahan mahasiswa ini sudah pernah dilakukan peneliti sebelumnya. Agnes Pisanski Peterlin (2008) yang dituangkan dalam artikelnya yang berjudul "The Thesis Statement in Translation of Academic Discourse: an Exploratory Study"meneliti tentang thesis statetment dalam terjemahan teks wacana akademik. ${ }^{4}$ Oscar Saz dkk. (2014) dalam artikelnya berjudul "Measuring of the Impact of Translation on Accuracy and Fluency of Vocabulary Acquisition of English" "meneliti tentang pengaruh penerjemahan terhadap akurasi dan kelancaran pemerolehan kosakata berbahasa Ingris pada mahasiswa nonpenutur asli tingkat menengah. ${ }^{5}$

tion, 2008, h. 11

3 Larson, M. L. Meaning-Based Translation: A Guide to Cross-Language Equivalence, (Lanham Md: University Press of America, 1984), h. 3.

4 Agnes Pisanski Peterlin. "The Thesis Stat ment in Translation of Academic Discourse: an Exploratory Study", h. 10

5 Oscar Saz, dkk. "Measuring of the Impact of Translation on Accuracy and Fluency of Vocabulary Acquisition of English", h. 49. www.sciencedirect.com Diakses tanggal 18 November 2015 
Reza Khany dalam artikelnya “Translation Students' Knowledge of Lexical Cohesion Paterns and Their Performance in the Translation of English Text"meneliti tentang korelasi antara pengetahuan mahasiswa terhadap pola-pola kohesi leksikal dan performansi mereka dalam menerjemahkan teks berbahasa Inggris. ${ }^{6}$

Berdasarkan berbagai masalah di atas, permasalahan utama dalam penelitian ini dirumuskansebagaiberikut:"Bagaimanakah terjemahan teks akademik bahasa Indonesia ke bahasa Arabmahasiswa program studi Pendidikan Bahasa Arab FITK UIN Syarif Hidayatullah Jakarta".

\section{Pengertian Terjemah}

MenurutLarson, kegiatan penerjemahan adalah menransfer arti dari bahasa sumber (BSu) ke reseptor. Hal ini dilakukan dengan dari menngalihkan bentuk bahasa pertama ke bahasa kedua dengan cara struktur semantik. Hal ini berarti yang sedang ditransfer harus tetap konstan, hanya perubahan bentuk. ${ }^{7}$ Penerjemahan terdiri dari mempelajari leksikon, struktur gramatikal, situasi komunikasi, dan budaya konteks teks bahasa sumber (BSu), menganalisisnya untuk menentukan maknanya, kemudian merekonstruksi makna yang sama dengan menggunakan leksikon dan struktur gramatikal yang sesuai dalam bahasa reseptor dan konteks budaya. ${ }^{8}$

Newmark mendefinisikan terjemah sebagaimana berikut:

6 Reza Khany, "Translation Students Know edge of Lexical Cohesion Patterns and Their Performance in the Translation of English Text", h.925. www.sciencedirect.com Diakses tanggal 20 November 2015, pukul 23:00.

Larson, M. L. Meaning-Based Translation: A Guide to Cross-Language Equivalence (Lanham Md: University Press of America, 1984), h. 3.

8 Larson, M. L. Meaning-Based Translation: A Guide to Cross-Language Equivalence, h. 3. "translation is a craft consisting in the attempt to replace a written message and/ or statement in one language by the same message and/or statement in another language". ${ }^{\prime} \quad$ Yaitu suatu keahlian yang meliputi usaha mengganti pesan atau pernyataan tertulis dalam suatu bahasa dengan pesan atau pernyataan yang sama dalam bahasa lain."

Hatim and Munday mendefinisikan terjemah sebagai "a phenomenon that has a huge effect on everyday life." ${ }^{\prime \prime}$ Definisi ini membawa implikasi bahwa penerjemahan dapat mencakup dua hal, yaitu sebagai sebuah proses dan sebagai sebuah produk. Iniberartibahwaistilahterjemahanmemiliki perspektif yang sangat berbeda. Pengertian pertama berfokus pada peran penerjemah dalam mengambil Bahasa sumber (BSu) dan mengubahnya menjadi Bahasa sasaan (BSa). Sedangkan pengertian kedua berfokus kepada produk penerjemahan yang dihasilkan oleh penerjemah Dalam bahasa Indonesia yang mengacu kepada proses disebut penerjemahan, sedangkan yang mengacu kepada produk disebut terjemahan. ${ }^{11}$

Kelly (2005) seperti dikutip Zohre Owji mendefinisikan penerjemahan sebagai keterampilan memahami bahasa sumber (BSu) dan mengubahnya ke dalam bahasa sasaran (BSa) dengan menggunakan register, pengetahuan latar belakang, dan sumber-sumber bahasa lainnya sesuai dengan tujuan yang telah ditetapkan. Oleh karena itu , seorang penerjemah adalah mediator dari kedua bahasa dan budaya

9 Peter Newmark, Approaches to Translation, (Britain: Cambridge University Press), 1991, h. 7

10 Basil Hatim dan Jeremy Munday, Translation: An Advance Resource Book. (London dan New York: Routledge, 2004), h.3.

11 Basil Hatim dan Jeremy Munday, Transl tion: An Advance Resource Book, h.3. 
yang dapat mentransfer BSu ke BSa. ${ }^{12}$

\section{Strategi penerjemahan}

Dalam terminologi penerjemahan, dari beberapa literatur yang ada, penggunaan kata strategi sering disamakan dengan teknik, metode, dan prosedur penerjemahan. Lorcher (1992:428) dalam Nababan mendefinisikan strategi penerjemahan sebagai procedures which the subjects employ in order to solve problems. Ada dua kata kunci yang perlu diperhatikan dari defenisi ini, yaitu: Procedures dan to solve problems. Kata kunci pertama berarti hal apa saja yang dilakukan penerjemah, sementara kata kunci kedua berarti bahwa semua hal yang dilakukan penerjemah dipicu adanya masalah yang muncul. Dengan demikian, dapat disimpulkan bahwa strategi dilakukan penerjemah apabila dia menemui masalah ketika melakukan kegiatan penerjemahannya. Selanjutnya, masalah timbul karena penerjemah telah merancang metode penerjemahan tertentu sebelumnya terhadap teks sumbernya. Kesimpulan Lorcher ini didapat dari penelitian proses yang dilakukannya untuk merekonstruksi strategi penerjemahan. ${ }^{13}$

Suryawinata dan Hariyanto menjelaskan bahwa yang dimaksud dengan strategi penerjemahan adalah taktik penerjemah untuk menerjemahkan kata atau kelompok kata, atau mungkin kalimat penuh bila kalimat tersebut tidak dapat dipecah lagi menjadi unit yang lebih kecil untuk diterjemahkan. Selanjutnya mereka juga menyebutkan bahwa strategi penerjemahan

12 Zohre Owji, "Translation Strategies." 17 D akses 6 December, 2014.

13 Donald J.Nababan, "Metode, Strategi, dan Teknik Penerjemahan: Sebuah Tinjauan Mendalam." Makalah, Kongres Linguistik Nasional XII Masyarakat LinguistiK Indonesia Komisariat Surakarta utdan Universitas Sebelas Maret, Surakarta, 3 September, 2007. sering juga disebut prosedur penerjemahan. Prosedur berarti urutan formal. ${ }^{14}$

Para ahli penerjemahan berbeda berbeda pendapat dalam menentukan jenis, kategorisasi dan klasifikasi strategi penerjemahan. Mereka mengklasifikasikan strategi penerjemahan sesuai dengan perspektif khusus dan sudut pandang mereka.

Adapun yang dimaksud dengan strategi penerjemahan dalam penelitian ini penambahan, pengurangan, dan transposisi.

\section{Metodologi Penelitian}

Penelitian ini dilakukan di Jurusan Pendidikan Bahasa Arab UIN Syarif Hidayatullah dalam rentang waktu 5 bulan, yaitu dari bulan Mei s.d. Oktober 2015. Penelitian ini secara khusus bertujuan untuk memperoleh data dan fakta tentang 1)Bagaimanakah strategi terjemahan teks akademik bahasa Indonesia ke dalam bahasa Arab dan 2) Bagaimanakah tingkat akurasinya dalam aspek peristilahan;

Berdasarkan tujuan tersebut, maka pendekatan penelitian yang dianggap relevan untuk digunakan dalam penelitian ini adalah pendekatan kualitatif. Sedangkan metode yang digunakan dalam penelitian ini adalah metode analisis isi. Pemilihan pendekatan dan metode ini dianggap relevan karena penelitian ini lebih menitikberatkan pada penelitian dokumen, dalam hal ini adalah hasil karya terjemahan.

Ada beberapa definisi mengenai analisis isi. Analisis isi (content analysis) adalah penelitian yang bersifat pembahasan mendalam terhadap isi suatu informasi tertulis atau tercetak dalam media massa. Analisis isi secara umum dapat diartikan juga sebagai metode yang meliputi semua

14 Zuchridin,Suryawinata, dan Sugeng Hariyanto. Translation: Bahan Teori Dan Penuntun Praktis Menerjemahkan. Cet. Ke-1, (Yogyakarta: Kanisius, 2003), h. 67. 
analisis mengenai isi teks, tetapi di sisi lain analisis isi juga digunakan untuk mendeskripsikan pendekatan analisis yang khusus. Krippendrorrff mendefinisikan analisis isi sebagai a research technique for making replicable and valid inferences from texts (or other meaningful matter) to the contexts of their use. ${ }^{15}$

Sumber data yang sekaligus menjadi objek dalam penelitian ini adalah contohcontoh otentik hasil pekerjaan mahasiswa jurusan PBA Semester VI FITK UIN Syarif Hidayatullah.

Data dalam penelitian ini berupa ungkapan verbal yang terdapat dalam hasil pekerjaan mahasiswa jurusan PBA.

Sesuai dengan pendekatan penelitian yang digunakan dalam penelitian ini, maka yang menjadi instrument dalam penelitian ini adalah peneliti sendiri.

Teknik pengumpulan data dalam penelitian tentang hasil penerjemahan memiliki karakteristik tersendiri, tidak seperti pada penelitian analisis isi lainnya. Berikut ini akan dipaparkan teknik-teknik pengumpulan data yang digunakan dalam penelitian ini:

1. Pengumpulan data dimulai dengan mengidentifikasi kata, frasa, klausa atau kalimat yang terdapat terdapat dalam $\mathrm{BSu}$ dan BSa yang tampak pada BSa nyamenyiratkan pemakaian strategi tertentu.

2. Kata, frasa, klausa atau kalimat yang diidentifikasi, terebut baikyang terdapat dalam bahasa sumber (BSu), maupun dalam bahasa sasaran (BSa) kemudian diberi nomor kemudian dicatat dalam kartu sehingga diperoleh pasangan kata, frasa, klausa atau kalimat dalam BSu Dan BSa.

15 Klaus Krippendorff, Content Analysis Introduction to Its Methodology, (London: Sage Publication, 2004), h. 83.
3. Langkah ketiga adalah membandingkan kata, frasa, klausa atau kalimat yang telah teridentifikasi dalam BSu dan BSa.

Adapun tahapan-tahapan dalam penelitian ini mengacu kepada teori Krippendrorrff . Tahapan-tahapan tersebut, adalah:

1. Pengunitan skema (unitizing);

2. Penyamplingan (sampling);

3. Perekaman/pengkodean (recording/ coding);

4. Pereduksian (pengurangan) atau penyederhanaan data (reducing);

5. Pengambilan simpulan (inferring);

6. Pemaparan jawaban pertanyaan penelitian (naratting). ${ }^{16}$

Sesuai dengan pendekatan yang digunakan dalam penelitian ini, maka analisis data dilakukan secara induktif. Karena penelitian ini tidak dimaksudkan untuk membuktikan hipotesis peneliti. Karena itu simpulan pada penelitian ini diperoleh berdasarkan analisis dokumen.

Teknik analisis data dalam penelitian ini dilakukan dengan langkah-langkah berikut.

1. Data diseleksi dengan menggunakan teknik kartu untuk menentukan orisinalitas terjemahan.

2. Data diklasifikasikan sesuai dengan kategori yang telah ditentukan sambil dilakukan pengkodean.

Sedangkanuntukmelihattingkatakurasi hasil terjemahan mahasiswa, analisis data dalam penelitian ini menggunakan kriteria penilaian yang terdapat dalam buku Pedoman bagi Penerjemah karya Rochayah Machali, dalam hal ini dibatasi hanya pada penilaian kebakuan atau ketepatan

16 Klaus Krippendorff, Content Analysis Intr duction to Its Methodology, h. 30. 
peristilahan.

Untuk keabsahan data penelitian ini memanfaatkan teknik triangulasi antarpeneliti yang dilakukan dengan cara menggunakan lebih dari satu orang dalam pengumpulan dan analisis data. Melalui teknik ini, pengetahuan mengenai informasi yang digali dari subjek penelitian menjadi cukup melimpah.

\section{Hasil Penelitian dan Pembahasan Hasil Penelitian}

Pada bab ini dikemukakan hasil penelitian, pembahasan dan temuan penelitian yang menggambarkan tentang hasil terjemahan teks akademik mahasiswa Pendidikan Bahasa Arab UIN Syarif Hidayatullah dari Bahasa Indonesia sebagai bahasa sumber (Bsu) ke Bahasa Arab sebagai bahasa sasaran (Bsa) dari segi ketepatan yaitu dengan melihat sejauh mana pesan itu tersampaikan, dan segi kejelasan makna dan istilah yang terungkap dalam teks tersebut.

Karena itu beberapa aspek penting yang menjadi fokus penelitian dalam hal ini mencakup aspek reproduksi makna dan aspek istilah. Pada akhirnya akan terlihat sejauh mana kualitas terjemahan yang dihasilkan atau dibuat oleh mahasiswa PBA.

Sumber data dalam penelitian ini adalah hasil terjemahan teks akademik yang memuat tentang istilah-istilah mengenai teori belajar dan psikologi belajar, kurikulum, metode pembelajaran, dan metode penelitian. Istilah-istilah ini sudah dikenal dan dipelajari oleh para mahasiswa jurusan PBA.

Para Mahasiswa Jurusan PBA adalah mahasiswa yang sedang belajar di semester VII. Mereka telah banyak mendapatkan materi tentang insya dan terjemahan. Di samping itu mereka juga telah mendapatkan materi kebahasaan, kependidikan, dan metode penelitian. Pemilihan objek penelitiankepadamerekasudahberdasarkan kompetensi yang dimiliki mereka dalam keterampilan menerjemahkan baik dari bahasa Arab ke bahasa Indonesia ataupun sebaliknya.

\section{Strategi Penerjemahan}

Untuk menganalisis strategi penerjemahan, maka dalam penelitian ini yang menjadi unit analisisnya dibatasi pada kata, frasa dan kalimat, dan teks dari 47 teks hasil terjemahan yang terpilih sebagai objek penelitian sekaligus sebagai data yang dianalisis untuk menemukan strategi yang digunakan penerjemah dalam menerjemahkan teks akademik dari bahasa Indonesia sebagai bahasa sumber (BSu) ke dalam bahasa Arab sebagai bahasa sasaran (BSa).

Satuan terjemahan adalah satuan bahasa sasaran (BSa) yang memilki padanannya dalam bahasa sumber (BSu). Satuan-satuan tersebut dapat berupa fonem, morfem, kata, frasa, kalimat, dan teks. ${ }^{17}$ Akan tetapi, dalam penelitian ini fonem dan morfem tidak dijadikan unit analisis karena keduanya hanya kadang-kadang saja menjadi unit analisis. Hal ini didasarkan pada argumen sebagaimana yang dikemukakan oleh Muntaha bahwa makna satuan yang tidak bisa dipecah dimiliki oleh bukan morfem, tetapi oleh satuan bahasa yang lebih tinggi tingkatnya; kata, frasa, kalimat, dan teks. ${ }^{18}$ Namun demikian pengambilan data tersebut dilakukan pada satuan lingual kalimat agar penerapan strategi penerjemahannya dapat diamati dalam konteks.

Dari sumber data yang diteliti dan

17 Salihen Moentaha, Bahasa dan Terjemahan (Bekasi: Kesaint Blanc, 2008), h. 33.

18 Salihen Moentaha, Bahasa dan Terjemahan, h. 33 
setelah dilakukan perbandingan antara $\mathrm{BSu}$ dengan BSa diperoleh 15 hasil terjemahan teks akademik ungkapan yang dipilih secara purposif dan merupakan merupakan hasil reduksi dari 47 hasil terjemahan teks akademik. Reduksi data ini didasarkan pada pertimbangan-pertimbangan: a) terdapat beberapa pasangan data yang setipe; b) terdapat beberapa BSu yang tidak memerlukan strategi penerjemahan khusus dikarenakan secara struktural dan semantis hampirsama dengan BSa terutama untuk terjemah-terjemah harfiyah dan c) keterbatasan waktu untuk meneliti;

Setelah dilakukan analisis terhadap sumber data, maka dalam teks akademik hasil terjemah ini teridentifikasi beberapa strategi penerjemahan yang digunakan penerjemah sebanyak 150 strategi yang diklasifikasikan menjadi 6 strategi. Sebaran strategi tersebut, disajikan melalui tabel berikut ini:

Tabel 1: Strategi Penerjemahan dan Sebarannya

\begin{tabular}{|c|l|c|c|}
\hline No. & \multicolumn{1}{|c|}{ Strategi } & F & \% \\
\hline 1 & Penambahan & 15 & $10 \%$ \\
\hline 2 & Penghilangan & 24 & $16 \%$ \\
\hline 3 & Transposisi & 22 & $14.7 \%$ \\
\hline 4 & Modulasi & 20 & $13.3 \%$ \\
\hline 5 & $\begin{array}{l}\text { Peminjaman } \\
\text { (Borrowing) }\end{array}$ & 18 & $12 \%$ \\
\hline 6 & Kalke (Calque) & 51 & $34 \%$ \\
\hline & Total & 150 & 100 \\
\hline
\end{tabular}

\section{a. Penambahan}

Penambahan adalah salah satu strategi dalam menerjemahkan dengan cara menambahkan katakata ke dalam BSa karena struktur bahasa menghendakinya seperti itu. ${ }^{19}$ Penambahan ini dapat terjadi

19 Zuchridin Suryawinata dan Sugeng Hariyanto, Translation: Bahasan Teori dan Penuntun Praktis pada aspek struktural dan dapat juga terjadi pada aspek semantik. Perbedaannya pada aspek semantik adalah penambahan ini dilakukan karena pertimbangan kejelasan makna. Dalam hal ini penerjemah memasukan informasi tambahan di dalam teks terjemahannya karena ia menganggap pembaca memerlukan hal tersebut. Informasi tambahan ini dapat diletakkan di dalam teks, di bagian bawah halaman, atau di bagian akhir halaman. ${ }^{20}$ Penambahan leksikal dalam BSu biasanya diperlukan jika maksud isi teks BSa diungkapkan dengan sarana lain, termasuk dengan sarana gramatikal. ${ }^{21}$ Biasanya penambahan dilakukan karena pertimbangan kejelasan makna. ${ }^{22}$

Dari sampel data yang dianalisis, teridentifikasi sekitar $20 \quad(9,52)$ $\mathrm{BSa}$ yang menggunakan strategi penambahan. Berikut contoh penerapan strategi penambahan yang digunakan penerjemah:

Tabel 2. Contoh Penerapan Strategi Penambahan

\begin{tabular}{|l|l|}
\hline & $\begin{array}{l}\text { Dalam memilih metode } \\
\text { pembelajaran, terdapat } \\
\text { beberapa faktor yang }\end{array}$ \\
Teks & harus dipertimbangkan \\
Sumber & guru, di antaranya: faktor \\
(TSu) & tujuan pembelajaran, \\
& bahan ajar, guru, siswa, \\
sarana dan prasarana, \\
media pembelajaran, dan \\
jumlah siswa.
\end{tabular}

Menerjemahkan (Yogyakarta: Kanisius, 2003), h. 67

20 Zuchridin Suryawinata dan Sugeng Hariyanto, Translation: Bahasan Teori dan Penuntun Praktis Menerjemahkan, h. 74

21 Salihen Moentaha, Bahasa dan Terjemahan, h. 69.

22 Zuchridin Suryawinata dan Sugeng Har yanto, Translation: Bahasan Teori dan Penuntun Praktis Menerjemahkan, h. 74 


\begin{tabular}{|c|c|}
\hline $\begin{array}{l}\text { Teks } \\
\text { Sasaran } \\
\text { (TSa) }\end{array}$ & طرل العديقة \\
\hline
\end{tabular}

Contoh tersebut memperlihatkan adanya strategi penambahan, yaitu kata مedua kata tersebut dianggap sebagai strategi penambahan karena tidak terdapat dalam teks sumber (TSu).

\section{b. Penghilangan}

Dari 6 strategi yang teridentifikasi, 24 (16\%) di antaranya merupakan strategi penghilangan. Strategi penghilangan atau juga disebut pengurangan artinya mengurangi elemen stuktural di dalam teks sasaran (TSa). Dalam strategi semantis pengurangan ini disebut dengan penghapusan yang berarti penghapusan kata atau bagian teks sumber (TSu) di dalam bahasa teks sasaran (TSa). Dengan kata lain, penghapusan berarti tidak diterjemahkannya kata atau bagian teks sumber (TSu) di dalam teks sasaran (TSa), dengan pertimbangan bahwa kata yang terdapat dalam teks sumber TSu tersebut dianggap tidak begitu penting bagi keseluruhan teks sasaran (TSa) dan biasanya agak sulit diterjemahkan. ${ }^{23}$ Penghapusan juga berarti meninggalkan satu unit makna dalam trks sumber TSu dalam teks sasaran (Tsa). Unit ini benar-benar tidak hadir secara implisit. Strategi ini dianggap agak

23 Zuchridin Suryawinata dan Sugeng Har yanto, Translation: Bahasan Teori dan Penuntun Praktis Menerjemahkan, h. 68 dan 75. kreatif meskipun tidak dianggap sebagai salah satu yang paling kreatif. ${ }^{24}$

Berikut contoh penerapan strategi penghilangan yang teridentifikasi dalam sumber data::

Tabel 3. Contoh Penerapan

Strategi Penghilangan

\begin{tabular}{|c|c|}
\hline $\begin{array}{l}\text { Teks } \\
\text { Sumber } \\
\text { (TSu) }\end{array}$ & $\begin{array}{l}\text { Landasan psikologis yang } \\
\text { terutama dijadikan pijakan } \\
\text { dalampembelajaranadalah } \\
\text { psikologi belajar dan } \\
\text { psikologi perkembangan. }\end{array}$ \\
\hline $\begin{array}{l}\text { Teks } \\
\text { Sasaran } \\
\text { (TSa) }\end{array}$ & خلفيها التعلم التعليم هي سيكوليك التي قام \\
\hline
\end{tabular}

Tabel tersebut menunjukkan adanya streategi penghilangan, kata "terutama" tidak terdapat terjemahannya dalam teks sasaran (TSa). Terdapat dua kemungkinan kata tersebut tidak diterjemahkan, yaitu karena sulit diterjemahkan atau karena dianggap tidak begitu penting, padahal jika kata tersebut dihilangkan akan menghilangkan sebagian makna yang terkandung dalam teks sumber (TSu), kata 'terutama' dapat bermakna 'paling penting'.

\section{c. Transposisi}

Dari 6 strategi yang teridentifikasi, $22(14,7 \%)$ di antaranya merupakan stratetgi transposisi. Strategi transposisi adalah salah satu strategi dalam penerjemahan yang melibatkan perubahan gramatikal bukan perubahan semantis. ${ }^{25}$ Transposisi juga berarti mengganti salah satu kelas kata

24 Anne Schjoldager, Understanding Transl tion, (Aarhus: Academica, 2008), h. 108.

${ }^{25}$ Basil Hatim dan Jeremy Munday, Translation: An Advance Resource Book. (London dan New York: Routledge, 2004), h. 353. 
yang terdapat dalam bahasa sasaran tanpa mengubah pesan. ${ }^{26}$ Newmark menyebutnya sebagai prosedur penerjemahan yang berkaitan dengan perubahan gramatikal dari BSu ke BSa. ${ }^{27}$ Strategi penerjemahan ini ditempuh jika penerjemah tidak menemukan struktur bahasayangsama dalam BSu dengan BSa. Misalnya penerjemah dapat mengubah kalimat majemuk menjadi beberapa kalimat tunggal, bentuk tunggal menjadi jamak atau sebaliknya, atau kategori verba menjadi nomina. ${ }^{28}$ Transposisi ini menjadi keharusan jika tanpa strategi ini BSu tidak tersampaikan, dan ia menjadi pilihan jika karena alasan gaya bahasa saja. $^{29}$

Berikut ini disajikan tiga contoh penggunaan strategi transposisi yang digunakan penerjemah.

\section{Tabel 4. Contoh Penerapan} Strategi Transposisi

\begin{tabular}{|c|c|}
\hline $\begin{array}{l}\text { Teks } \\
\text { Sumber } \\
\text { (TSu) }\end{array}$ & $\begin{array}{l}\text { Psikologi belajar mengkaji } \\
\text { tentang hakikatbelajar dan } \\
\text { teori-teori belajar, serta } \\
\text { berbagai aspek perilaku } \\
\text { individu lainnya dalam } \\
\text { belajar yang semuanya } \\
\text { dapat dijadikan sebagai } \\
\text { bahan } \\
\text { sekaligus pertimbangan } \\
\text { pengembangan kurikulum. }\end{array}$ \\
\hline
\end{tabular}
h. 90 .

${ }^{26}$ Anne Schjoldager, Understanding Translation,

27 Peter Newmark, A Textbook of Translation, UK: Prentice Hall International, 1988, h. 85.

28 Syihabuddin, Penerjemahan Arab Indonesia (Bandung: Humaniora, 2005), h. 81.

29 Zuchridin Suryawinata dan Sugeng Har yanto, Translation: Bahasan Teori dan Penuntun Praktis Menerjemahkan, h. 68.

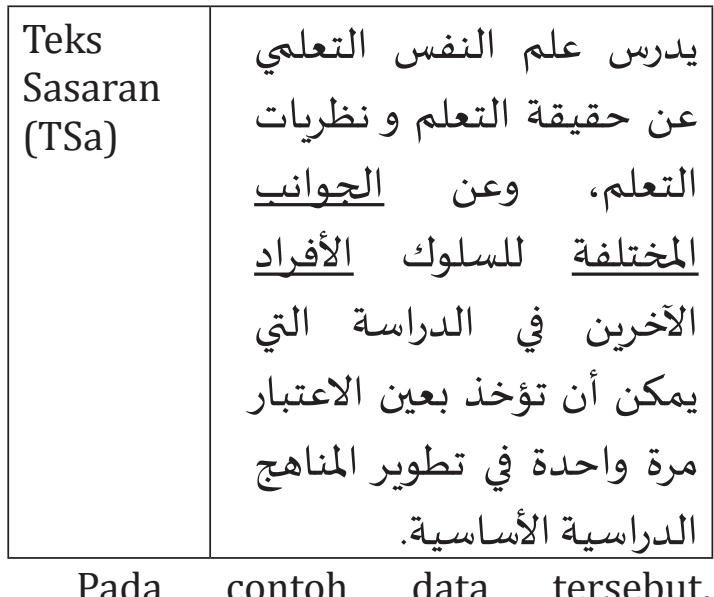

penerjemah melakukan strategi transposisi, yaitu menerjemahkan frasa 'berbagai aspek' yang merupakan 'frasa nominal' ke dalam 'frasa ajektiva', demikian juga dalam kata 'individu', dari kata tunggal diterjemahkan menjadi jamak.

\section{d. Modulasi}

Dari 6 strategi yang teridentifikasi $20(13,3 \%)$ di antaranya merupakan stratetgi modulasi. Modulasi adalah strategi untuk menerjemahkan kata, frase, klausa, atau kalimat. Jika dalam strategi transposisi yang terjadi pergeseran struktur, maka dalam strategi modulasi yang terjadi adalah pergeseran makna. ${ }^{30}$

Modulasi ini menjadi sebuah keharusan dilakukan penerjemah jika suatu kata, frasa, atau struktur tidak ada padananya dalam BSa, atau jika terjadi pada penerjemahan kata yang hanya sebagian aspek maknanya dalam BSu dapat diungkapkan dalam BSa, yaitu dari makna yang bernuansa khusus ke umum. Sedangkan modulasi menjadi sebuah kebebasan jika hanya untuk memperjelas makna. ${ }^{31}$

30 Rochayah Machali, Pedoman bagi Penerjemah, (Bandung: Kaifa, 2009), h. 99.

31 Rochayah Machali, Pedoman bagi Penerj mah, h. 100 
Tabel 5. Contoh Penerapan Strategi Modulasi

\begin{tabular}{|c|c|}
\hline $\begin{array}{l}\text { Teks } \\
\text { Sumber } \\
\text { (TSu) }\end{array}$ & $\begin{array}{l}\text {... menyangkut prinsip } \\
\text { yang berkenaan dengan } \\
\text { tujuan pendidikan, prinsip } \\
\text { berkenaan dengan pemili- } \\
\text { han isi pendidikan, prinsip } \\
\text { berkenaan dengan pemili- } \\
\text { han kegiatan belajar men- } \\
\text { gajar, prinsip berkenaan } \\
\text { dengan pemilihan media } \\
\text { pembelajaran, dan prinsip } \\
\text { berkenaan dengan peni- } \\
\text { laian. }\end{array}$ \\
\hline $\begin{array}{l}\text { Teks } \\
\text { Sasaran } \\
\text { (TSa) }\end{array}$ & 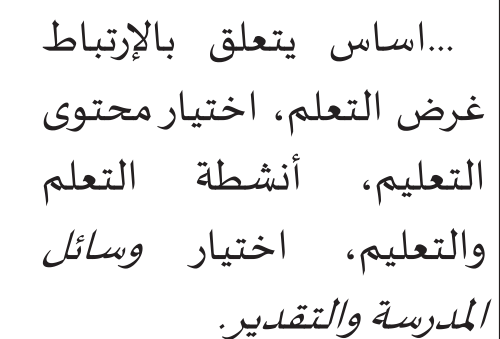 \\
\hline
\end{tabular}

Tabel tersebut menunjukkan contoh penerapan strategi modulasi dalam penerjemahan. Frasa 'media pembelajaran' diterjemahkan menjadi , dan kata 'penilaian' menjadi . Dalam hal ini penerjemah mengubah sudut pandangnya dengan mencari makna yang tersirat dari frase atau kata tersebut.

\section{e. Peminjaman/Pungutan}

Dari 6 strategi yang teridentifikasi sekitar 18 (12 \%) di antaranya merupakan stratetgi peminjaman atau pungutan. Peminjaman atau pungutan adalah strategi penerjemahan yang membawa kata pada bahasa sumber (BSu) ke dalam bahasa sasaran (BSa). Strategi ini biasanya digunakan untuk menunjukkan penghargaan terhadap kata-katatersebutatau dapatjugakarena belum ditemuipenerjemahpadanan kata dalam BSu dalam BSa. Peminjaman ini termasuk di dalamnya transliterasi dan naturalisai. Transliterasi adalah strategi penerjemahan yang mempertahankan BSu tersebut secara utuh, baik bunyi maupun tulisannya. Sedangkan naturalisasi merupakan lanjutan dari naturalisasi kata-kata dalam BSu yang pengucapan dan penulisannya disesuaikan dengan aturan bahasa pada $\mathrm{BSa}^{32}$

Berikut contoh penerapannya dalam data:

Tabel 6. Contoh Penerapan Strategi Peminjaman/Pungutan

\begin{tabular}{|c|c|}
\hline $\begin{array}{l}\text { Teks } \\
\text { Sumber } \\
\text { (TSu) }\end{array}$ & $\begin{array}{l}\text { Teori belajar bersumber } \\
\text { dari aliran-aliran psikolo- } \\
\text { gi. Landasan psikologis } \\
\text { yang terutama dijadikan } \\
\text { pijakan dalam pembelaja- } \\
\text { ran adalah psikologi bela- } \\
\text { jar dan psikologi perkem- } \\
\text { bangan. }\end{array}$ \\
\hline $\begin{array}{l}\text { Teks } \\
\text { Sasaran } \\
\text { (TSa) }\end{array}$ & 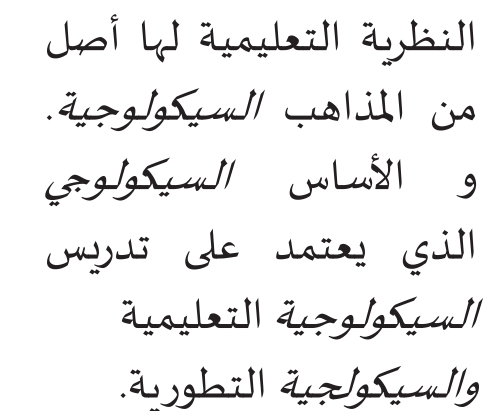 \\
\hline
\end{tabular}
penerjemah melakukan peminjaman atau pungutan dari BSu yaitu kata "psikologi" yang dimodifikasi dengan menambahkan akiran "ya" yaitu pada yang menunjukkan makna sebuah bidang ilmu. sehingga tampak seperti bahasa sasaran (BSa).

\section{f. Calque}

$\begin{array}{cr}\text { Calque adalah } & \text { strategi } \\ \text { penerjemahan yang mirip dengan } & \text { da }\end{array}$

32 Zuchridin Suryawinata dan Sugeng Har yanto, Translation: Bahasan Teori dan Penuntun Praktis Menerjemahkan, h. 71. 
perbedaannya terletak pada struktur BSu yang masih muncul dalam BSa atau leksikal yang dipertahankan, namun masih mengikuti struktur BSa.

Dari 6 strategi yang teridentifikasi, 51 (34\%) di antaranya merupakan stratetgi penerjemahan dengan menggunakan strategi calque. Berikut ini merupakan contoh penerapan calque yang teridentifikasi dari sumber data:

\section{Tabel 8. Contoh Penerapan Calque}

\begin{tabular}{|c|c|}
\hline $\begin{array}{l}\text { Teks } \\
\text { Sumber } \\
\text { (TSu) }\end{array}$ & $\begin{array}{l}\text { Metode pengajaran ba- } \\
\text { hasa asing memiliki be- } \\
\text { ragam metode. Di antara } \\
\text { metode-metode tersebut } \\
\text { adalah: metode tata baha- } \\
\text { sa terjemah, metode lang- } \\
\text { sung, metode membaca, } \\
\text { metode dengar-ucap, me- } \\
\text { tode komunikatif } \text { metode } \\
\text { respons fisik total, metode } \\
\text { sugestopedia, metode ala- } \\
\text { miah, dan metode eklektik. }\end{array}$ \\
\hline $\begin{array}{l}\text { Teks } \\
\text { Sasaran } \\
\text { (TSa) }\end{array}$ & 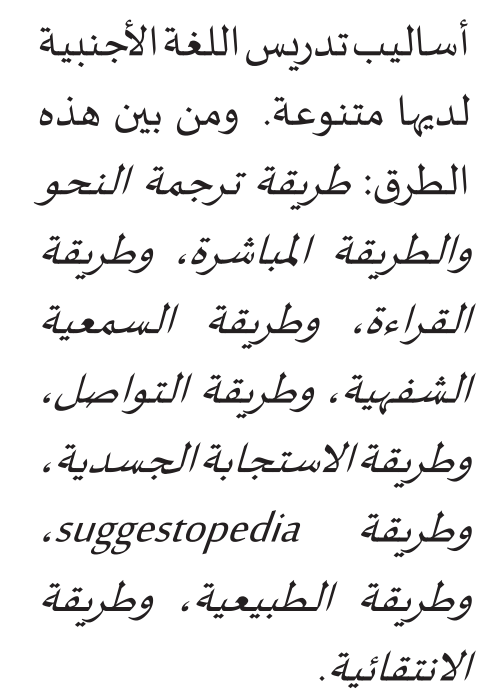 \\
\hline
\end{tabular}

Kata yang bergaris bawah pada tabel di atas menunjukkan penggunaan strategi calque dalam penerjemahan, yaitu kata-kata tersebut diterjemahkan secara harfiah atau kata per kata. Contohnya 'metode qawa'id terjemah' diterjemahkan menjadi طريقة ترجمة النحو, walau secara urutan berbeda dan mengubah artinya. 'Metode dengar ucap' طريقة السمعية 'Denjadiemahkan menji الشفهية, walaupun secara struktur terdapat kesalahan yaitu pada kata . طريقة seharusnya الطريقة .

Secara struktural frasa tersebut mengikuti frasa yang terdapat dalam bahasa sumber, sedangkan secara semantis teks BSu tersebut masih meminjam leksikal yang terdapat dalam bahasa sumber (BSu).

Berdasarkan strategi penerjemahan yang teridentifikasi dari sumber data, strategi penerjemahan yang paling dominan yang digunakan penerjemah secara berurutan adalah calque, penghilangan, transposisi, modulasi, peminjaman, dan penambahan.

\section{Akurasi dalam Peristilahan}

Keakuratan peristilahan merupakan salah satu aspek yang paling krusial dalam penerjemahan teks akademik. Suatu hasil terjemahan baik pada tataran kata, frasa atau kalimat akan diaggap akurat jika sepadan atau ekuivalen antara teks sumber (Tsu) dan dan teks sasaran (Tsu), karena itu meskipun dalam menerjemah terdapat strategi pengurangan dan penambahan, hal tersebut tidak dimaksudkan untuk mengubah pesan atau informasi yang terdapat dalam teks sumber (Tsu), terutama dalam penerjemahan teks-teks bergenre akademik.

Dalam penelitian ini terdapat 34 peristilahan bergenre akademik tentang teori belajar dan psikologi belajar, kurikulum, metode pembelajaran, dan 
metode penelitian yang diteskan kepada mahasiswa. Dengan demikian jika dikalikan dengan jumlah naskah yaitu 15, maka diperoleh 510 kejadian. Dari 510 kejadian tersebut, diperoleh 150 kejadian atau sekitar 29,4\% yang dianggap tidak akurat dalam menggunakan istilah akademik. Sebagai contoh, 'pengembangan المنهج kurikulum' diterjemahkan menjadi التطوري, 'evaluasi' diterjemahkan menjadi التقدير, 'studi korelasional' diterjemahkan menjadi دراسـة مقارنة, 'media pembelajaran' diterjemahkan menjadi وسائل المدرسـة dan contoh-contoh lainnya. Dengan demikian pada tataran akurasinya, hasil terjemahan mahasiswa ini bisa dianggap masih memiliki tingkat akurasi yang tinggi.

\section{Pembahasan}

Sesuai dengan fokus penelitiannya, pembahasan dalam penelitian ini difokuskan pada analisis penggunaan strategi dan dampaknya terhadap kualitas terjemahan.

Pada subjudul strategi penerjemahan teridentifikasi 6jenisstrategi. Berdasarkan analisis data terhadap dua teks yaitu teks sumber (TSu) dan teks sasaran (TSa) maka dapat diketahui bahwa strategi yang paling dominan digunakan penerjemah adalah strategi calque. Hal ini dapat dipahami mengingat teks-teks bergenre akademik berbeda dengan teks sastra yang sering menggunakan bahasa kiasan, sementara itu teks bergenre akademik menggunakan bahasa yang normal, walaupun bersifat eksklusif karena hanya yang memiliki bidang tertentu yang dapat memahaminya.

Namun demikian ada beberapa catatan yang berkaitan dengan penggunaan strategi penambahan ini dan pengurangan. Jika diamati tampaknya penggunaan strategi penambahan ini tidak selalu dapat memperjelas pesan yang ada dalam teks sumber (TSu), bahkan kadang sebaliknya. Di samping itu penambahan juga baik pada tataran struktural maupun pada tataran semantis harus tetap memperhatikan struktur yang berlaku pada bahasa sasaran (BSa) sehingga diperoleh penerjemahan yang wajar. Di samping itu ketika penerjemah akan menggunakan strategi penambahan harus memperhatikan apakah penambahan tersebut berdampak pada efektif tidaknya teks yang ada dalam bahasa sasaran, terutama pada tataran kalimat. Itulah sebabnya seorang penerjemah tidak hanya harus memiliki kecakapan dalam bahasa sumber (BSu) saja, akan tetapi ia juga harus memiliki kecakapan dalam bahasa sasaran (BSa).

Demikian juga pada strategi transposisi. Dalam proses penerjemahan, pemahaman penerjemah atas hubungan fungsional antara unsur-unsur sintaksis dan kategori kata sangat berperan dalam mengungkapkanmaknadanmaksud penulis dalam teks bahasa sasaran (BSa). Ketika penerjemah merekonstruksi struktur mungkin dia harus mentransposisikan unsur-unsur frase dan klausa ke dalam bahasa sasaran (BSa). Inilah yang mengakibatkan terjadinya transposisi fungsi dan kategori dalam suatu kalimat. Dalam bahasa Indonesia, fungsi tersebut dapat berbentuk subjek (S), predikat (P), objek (O), pelengkap (Pel.) dan (K). Adapun yang dimaksud dengan kategori ialah nomina $(\mathrm{N})$, verba $(\mathrm{N})$, ajektiva $(\mathrm{A})$, pronominal (Pro.), numeralia (Num.), dan kata sarana $(\mathrm{KS}){ }^{33}$

Sementara itu dalam bahasa Arab dikenal 6 fungsi dan setiap fungsinya diisi oleh satu kategori. Keenam fungsi tersebut adalah musnad ilaih (subjek), musnad 33 Syihabuddin, Penerjemahan Arab Indonesia, h. 87. 
(predikat), dhamîmah (suplemen) yang terdiri atas mukammil (pelengkap), tabi' (keterangan), râbith (konektor), dan tahwîl (transformasi). ${ }^{34}$

Dari aspek akurasinya, meskipun hasil terjemahan mahasiswa dalam menerjemah istilah-istilah akademik masih memiliki tingkat akurasi yang tinggi, akan tetapi dari aspek struktur yang digunakan tingkat akurasinya masih rendah terbukti masih banyak ditemukan struktur-struktur yang tidak memenuhi kaidah gramatika bahasa Arab. Sebagai contoh banyak ditemukan kesalahan penggunaan tarkîb washfi (frasa adjektiva) dan tarkîb idhâfi (frasa nomina), di antaran contoh-contoh tersebut: الدراسة علم النفسر العوامل الهدف التعليه , المادة التعليه, طريقة yang semuanya merupakan contoh kesalahan dari aspek struktur.

\section{Simpulan}

Berdasarkan analisis terhadap hasil terjemahan teks akademik mahasiswa PBA FITK UIN Syarif Hidayatullah dari bahasa Indonesia ke bahasa Arab, diperoleh kesimpulan bahwa dari 150 strategi yang teridentifikasi, ditemukan 6 bentuk strategi penerjemahan yang muncul dari teks otentik hasil terjemahan mahasiswa dari bahasa Indonesia ke bahasa Arab, yaitu strategi penambahan, pengurangan, transposisi, modulasi, peminjaman, dan calque. Dari keenam strategi tersebut yang paling dominan digunakan mahasiswa adalah calque.

Dari aspek peristilahan yang digunakan dalam bahasa sasaran (BSa), penggunaan istilah akademik dapat dianggap masih memiliki tingkat akurasi yang tinggi walau masih terbatas pada tataran makna, dalam arti peristilahan yang digunakan mayoritas sudah benar, baku dan jelas, sementara

\footnotetext{
34 Syihabuddin, Penerjemahan Arab Indonesia,
} h. 87. dari aspek akurasi struktur bahasa masih ditemukan banyak kesalahan, karena masih banyak struktur-struktur bahasa yang menyalahi gramatika bahasa Arab.

Berdasarkan temuan tersebut terdapat beberapa implikasi yang perlu mendapat perhatian. Karena masih ditemukannya istilah-istilah yang dianggap kurang baku dan kurang akurat dalam hasil terjemahan mahasiswa, maka materi terjemah perlu disesuaikan dengan kebutuhan akademik mahasiswa. Di samping itu karena masih ditemukan kesalahan yang berkaitan dengan kesalahan gramatikal dalam hasil terjemahan mahasiswa, seyogyanya dosen mata kuliah terjemah agar lebih detail dalam mengoreksihasilterjemah mahasiswa, secara individu maupun kolektif yang selanjutnya mahasiwa diberi feed back (umpan balik) sehingga kesalahan dalam gramatika dapat diminimalisasi.

\section{Daftar Rujukan}

Baker, Mona, In other words: A course book on translation London: Routledge, 2001.

Hatim, Basil dan Jeremy Munday, Translation: An Advance Resource Book. London dan New York: Routledge, 2004.

Krippendorff, Klaus Content Analysis Introduction to Its Methodology, London: Sage Publication, 2004.

Moentaha, Salihen Bahasa dan Terjemahan, Bekasi: Kesaint Blanc, 2008.

Newmark, Peter. About Translation, Multilingual Matters LTD. 1991.

Newmark, Peter Approach es to Translation, Britain: University Press, Cambridge, 1991.

Schjoldager, Anne. Understanding Translation. Aarhus: Academica. 2008. 
Larson, M. L. Meaning-Based Translation: A Guide to Cross-Language Equivalence, Lanham Md: University Press of America, 1984.

Nababan, Donald J. "Metode, Strategi, dan Teknik Penerjemahan: Sebuah Tinjauan Mendalam." Makalah, Kongres Linguistik Nasional XII Masyarakat LinguistiK Indonesia Komisariat Surakarta utdan Universitas Sebelas Maret, Surakarta, 3 September, 2007.

Oscar Saz dkk. (2014): "Measuring of the Impact of Translation on Accuracy and Fluency of Vocabulary Acquisition of English", h. 49. www.sciencedirect.com Diakses tanggal 18 November 2015

Owji, Zohre "Translation Strategies." 17 (2013). Diakses 6 December, 2014.
Peterlin, Agnes Pisanski (2008): "The Thesis Statement in Translation of Academic Discourse: an Exploratory Study" The Journal of Specialised Translation.

Reza, Khany. "Translation Students Knowledge of Lexical Cohesion Patterns and Their Performancein the Translation of English Text", www.sciencedirect.com Diakses tanggal 20 November 2015.

Syihabuddin, Penerjemahan Arab Indonesia, Bandung: Humaniora, 2005.

Zuchridin,Suryawinata, dan Sugeng Hariyanto. Translation: Bahan Teori Dan Penuntun Praktis Menerjemahkan. Cet. Ke-1, Yogyakarta: Kanisius, 2003. 